\begin{tabular}{lcl}
\hline \multicolumn{1}{c}{ A N N A L E S } \\
UNiversitatis & MARIAE CURIE-SKŁODOWSKA \\
LUBLIN - POLONIA & 2016 \\
\hline
\end{tabular}

Faculty of Journalism and Mass Communication, St. Kliment Ohridski Sofia University, Bulgaria

\author{
LILIA RAYCHEVA
}

\title{
Challenges of Bulgarian Transformations to Contemporary Media Developments (1989-2014)
}

\begin{abstract}
The paper examines in a three-folded way the media developments in Bulgaria during the last quarter of a century in several aspects: political, legal, technological, social and professional. It also discusses some major political and social implications of the new roles of the audiences viewed through the prism of pre-election campaigning and public activism. The text examines some main challenges of the media transformation to media freedoms, such as politicization of media and mediatization of politics in pre-election campaigning, as well as the growing significance of the media ecosystem (the mutual collaboration between the blogosphere and the traditional media).
\end{abstract}

Key words: media, transformation, audiences, media ecosystem, democratization

\section{INTRODUCTION}

The period of transformation to democracy and market economy has posed significant social challenges to the population in Bulgaria. The transition was slowed down by delayed legislation, aggressive political behavior and underdeveloped markets. All this caused a rapid impoverishment, a high rate of unemployment and a loss of established social benefits like free healthcare and free education. Thus, the country entered the $21^{\text {st }}$ century under the Currency Board. Among the major political achievements during that transformation period of nearly 25 years were the stabilization of pluralistic political life in the country, joining NATO in 2004, and the accession to the EU in 2007. 
The transition to civil society and market economy in Bulgaria involved also a number of challenges in mass media developments. These included the general insufficiency of financial and technological resources and lack of professional standards. Media competition stimulated the first dynamic open markets in the country, which established well-developed media consumption patterns. Although the Bulgarian public was offered a highly varied media menu, expectations that the media would aid the processes of democratization in a purposeful and effective manner proved unrealistically high. Media were in need of transformation themselves. Change of property and single-party control was not sufficient for rendering them professional. Although the guild has adopted its Ethical code in 2004, it failed to build the mechanisms for sustaining it and in many cases reacted inadequately to important and publicly significant issues, as well as to a number of professional problems [Union of Bulgarian Journalists 2004]. Deprofessionalization and tabloidization trends accompanied the transformation period. A number of professional journalistic unions were established, but they failed to defend basic professional rights and responsibilities. Similarly to the politicians, former and newly hatched, journalists were not ready to shoulder to the full their new role and the subsequent responsibilities of a Fourth Estate in a society under transformation.

Discussing in 2008 the presence of PSB in the post-communist area, Karol Jakubowicz outlines four groups of the analyzed 26 Central and Eastern European countries: competitive democracies, concentrated political regimes, war-torn regimes, noncompetitive political regimes. Then Bulgaria is mapped in the second group - the one of the concentrated political regimes [Jakubowicz 2008]. In 2015, Bogusława Dobek-Ostrowska places Bulgaria in the politicized CEE media model (the other three being liberal hybrid, media in transition, and authoritarian) [Dobek-Ostrowska 2015].

\section{THE DYNAMICS OF THE MEDIA SYSTEM ${ }^{1}$}

To understand the profound transformation of the mass media system and its development trends in Bulgaria, one should go back to the roots of political upheaval after the falling of the Berlin Wall. Following the profound democratic developments throughout all Eastern European countries after 1989, the tendency to fundamental changes in the mass media system became irreversible. The new Bulgarian Constitution guaranteed freedom of expression for all citizens. Article 40 (1) specifically defended freedom of mass media: "The press and the other mass information media shall be free and shall not be subjected to censorship" [Constitution 1991]. Along with the overall economic and political crisis of the time, the transformation of the mass media system developed on practical, trial-and-error efforts, rather than on a legal basis.

1 The topic has been analyzed by the author in the following publications: The Challenges of Digitalization to Bulgarian Public Service Media, [in:] Public Value Report, K. Mitschka (ed.), ORF, Austria 2012 , 
Of all institutions in the country, the mass media facilitated the transformation towards democracy and market place economy in the fastest and most profound way. The processes of decentralization, liberalization and privatization began spontaneously, however, with no sharing of common perspectives. In a short time, a completely new journalism landscape was formed in which different patterns of media consumption and new advertising strategies were introduced. The emerging professional principles and styles of journalism were created and mastered ad hoc, in an atmosphere of turbulent events. It turned out that the media were fulfilling the dual function of transmitters of protest and accelerators of political change. The transition period has provided journalists with a strong hold on public opinion. Thus, the mass media system often operated as a Fourth Estate, influencing social attitudes, political opinions and decision-making on national priorities.

Political pluralism and varied media environment in Bulgaria still experience systematic difficulties. The still-in-the-make civil society fails to assist the creation of a stable public basis for professional journalism. According to the World Press Freedom Index 2015, Bulgaria has dropped down to $106^{\text {th }}$ place (among 180 countries), which proves that freedom of speech and independent journalism is still convertible phraseology for most of the media outlets and for many a non-governmental organization disbursing the funds of European and Transatlantic institutions [Reporters 2015]. Their activities proved erratic, limited and ineffective in the long run.

Many challenges were encountered in the process of establishing the new press. The early 1990s heralded the age of deregulation of the print media leading to a tremendous

pp. 11-18; The Bulgarian-Language Media Diaspora, co-authored with P. Stoyanova, [in:] Migration, Diaspora, and Information Technology in Global Societies, L. Fortunati, R. Pertierra, J. Vincent (eds.), Routledge, New York 2012, pp. 139-153; Television: The Good, the Bad and the Unexpected Challenges of ICT, [in:] Participation in Broadband Society: Interacting with Broadband Society, L. Fortunati, J. Gebhardt, J. Vincent (eds.), Peter Lang GmbH, Frankfurt am Main, Germany 2010, vol. 1, pp. 187-205; Television: the Challenges of the Digital Dividend to Viewers Participation, [in:] The Good, the Bad and the Challenging. The User and the Future of Information and Communication Technologies, B. Sapio, L. Haddon, E. Mante-Meijer, L. Fortunati, T. Turk \& E. Loos (eds.) Office for Official Publications of the European Communities, Luxemburg 2009, vol. 1, pp. 477-485; Mass Media Developments in Bulgaria, [in:] Press Freedom and Pluralism in Europe. Concepts and Conditions, A. Czepek, M. Hellwig, E. Novak (eds.), Intellect, Bristol, UK 2009, pp. 165-176; The Patchwork of Bulgarian Media, "Global Media Journal" - Polish Edition, 2008, no. 1(4). Available at: http://www.globalmediajournal.collegium.edu.pl/artykuly/wiosna\%202008/raycheva-bulgaria. pdf; Television: the Challenges of Pluralism to Media Regulation, "Central European Journal of Communication"- Official Journal of the Polish Communication Association, vol. 1, no. 1, 2008, pp. 63-78; Television in Bulgaria on the Net, [in:] The Impact of Internet on the Mass Media in Europe, N. Leandros (ed.), Abramis, Bury St. Edmunds, Suffolk (UK and USA) 2006, pp. 503-513; Mass Media's Changing Landscape in Bulgaria, co-authored with Todor Petev, [in:] Business as Usual. Continuity and Change in Central and Eastern Europe, D. Paletz, K. Jakubowicz (eds.), Hampton Press, Inc. Cresskill, New Jersey, USA 2003, pp. 73-109; Mass Media in Bulgaria, [in:] A Source Book. Dortmund: ENTIRE - Working Papers in International Journalism, 2003, p. 44; The Challenges of Internet Media to Traditional Media System in Bulgaria, [in:] Towards New Media Paradigms: Content, Producers, Organisations and Audiences, R. Salaverria, S. Sádaba (eds.), Pamplona (Spain) 2003, pp. 531-545; Mass Media System in Bulgaria (1989-1999), co-authored with T. Petev, "The Global Network", Bucharest: no. 13, 2000, pp. 7-17; The Dynamics of the Electronic Mass Media System in Bulgaria (1989-1999), "The Global Network", Bucharest: no. 13, 2000, pp. 37-57. 
change in the entire industry. The tight ideological control over the mass media was replaced by economic motives. Some factors such as the soaring prices of newsprint, printing services and distribution expenses sped up the process of catering to audience expectations and needs rather than narrow political interests. In this situation, it was quite natural for advertising to prosper and the profits from it became the main economic resource for print media. In the post-1989 period, many new publications did come and go. Right after the political changes, extreme media partisanship has been developed. Political pluralism fostered the emergence of multi-party press. A wide range of highly varied editions quickly took shape: political, popular, quality, topical, and specialized publications. This brought the decrease of the party press circulation. A new press emerged which declared itself politically independent. These periodicals quickly gained the largest audience share and took over the expanding volume of advertising. Under the auspices of privatization and commercialization, aggressive press corporations laid down the basis of media concentration.

Data provided by the National Statistical Institute vividly show the trends in the development of the media within the first two decades of the transition period. As for printed media, 301 newspapers (17 dailies) with an annual circulation of 895,265,000 were published in 1989, compared to 436 newspapers (70 dailies) with an annual circulation of $370,789,000$ twenty years later, in 2008. The corresponding figures for magazines and bulletins were 827 with annual circulation of 57,849,000 in 1989 vs. 827 with annual circulation of $57,849,000$ in 2008 . There has been a significant trend for preserving and even increasing diversification of supply, while, at the same time, considerably reducing circulation. Currently, due to the economic crisis the number of the print media has been reduced: 307 newspapers ( 54 dailies) with annual circulation of 324,310,000 and 668 magazines and bulletins with annual circulation of 27,831,000 are on the market place [National 2014].

In contrast to the turbulent transformation in the print media, the changes in the electronic media were slower, incomplete and lacked general consistency. They started and were carried out in an atmosphere of deregulation - the Radio and Television Act, as well as the Telecommunications Act was adopted only in 1998. Both of them have been amended frequently. Bulgaria joined the Television without Frontiers Directive (1989) and later ratified the European Union's Convention on Transfrontier Television (1997). Current media legislation has been closely aligned with EU regulations. The two national institutions that regulate the electronic media - the Council for Electronic Media (CEM) and the Communications Regulation Commission (CRC), jointly issue radio and TV licenses and register cable and satellite broadcasters. CEM (formerly The National Council for Radio and Television) is the regulatory body that monitors compliance with the Radio and Television Act, including issues such as advertising, sponsorship, product placement, copyright, and protection of minors. The Council also considers complaints by citizens and organizations. CRC (formerly The State Commission of Telecommunications) enforces the Telecommunications Act and manages the radio frequencies spectrum. 
For 25 years, a highly saturated radio and TV landscape has been gradually established.

Several telling trends in radio program dynamics could be discerned during this period of transition. Radio broadcasting had displayed an enormous increase. In 1988, prior to the political changes, some 46,810 hours of programming were aired. In 1989, the number had increased to 48,498 hours; in 1993, the introduction of private radio bounced the total number of on-air hours to 161,278 . By 2008, twenty years after the changes, the public was enjoying 797,683 hours of programming, more than sixteen times the number of hours broadcast in 1988. Program supply had been strongly diversified. The local radio stations had been developing a clear-cut public profile as well as introducing technological innovations, such as computer-run, RDS and online versions of the regular radio programs. The introduction of new styles, formats and standards leads to steady segmentation of the radio audiences. The dynamics of structure and format of the programmes is notable: the news programs drastically increase: from 19,090 hours in 1988 to 26,154 hours in 1989, 72,358 hours in 1994 and 92,070 hours in 2008 [National 2009].

Compared to the other media, changes in television came much more slowly. Some major reasons for that included: state monopoly over national telecasting; political pressures resulting in frequent replacements of TV executives (in the course of 25 years, fifteen General Directors in succession headed the public National Television and only three of them have completed their office term without suspension); the lack of research and development concepts and strategies; inefficient management; economic constraints, obsolete equipment, etc.

The introduction of commercial television from 1994, encouraged program diversification in the national TV landscape. A diverse TV market was gradually established in the country. Meanwhile, the almost uncontrolled reception of satellite, transborder and cable programs exerted significant pressure on the domestic channels. Infiltration of foreign audio-visual products had an equally strong impact on national broadcasting policies.

The TV program dynamics was accompanied by several important trends. TV broadcasting had displayed a significant increase. In 1988, prior to the political changes, 5,886 hours of TV programming were aired. A dramatic growth of 500 hours of telecasts was registered during the critical year of 1989. By 1994, when private television was officially introduced, audiences enjoyed 7,178 hours of TV programming, while in 2008 , the number of hours reached 747,036 - more than 120 times increase! [National 2009]. The diversified program supply encouraged higher audience selectivity. Digitalization, mobile and web casting are the current technological challenges to the Bulgarian TV broadcasters.

Although the advertising market is still not very big, the radio and TV environment is oversaturated. Lack of clarity about the media ownership obscures the fact how dependent the electronic media can be on political and business interests and impacts on the media policies. The weak market, which fails to maintain the numer- 
ous licensed radio and TV stations, has left a loophole for companies with capitals of doubtful origin. By the present moment the legal, technological, regulatory and social framework is rather contradictory and often serves corporative interests.

In 2014, 337 radio stations and 187 television channels are registered, operating on national, regional and local level terrestrially, via cable or via satellite. Radio and television broadcasting on the Internet is rigorously developing [Council 2014]. The privately owned radio and TV stations undoubtedly challenged the monopoly of the state-owned public television. However, the public service broadcasters enjoy the highest audience credibility: Bulgarian National Television is approved by $72.5 \%$ of the population and Bulgarian National Radio - by $58.6 \%$, compared to other institutions such as police $-42.3 \%$, army $-41.9 \%$, Parliament $-23.4 \%$, and Court $-17.0 \%$ [NCPOR 2012].

The increasing popularity of the Internet during the last two decades has definitely impacted the media system status quo. However, the online media business model is still problematic. The combination of content sales, subscription fees and advertising revenues can not bring sufficient income to assure content variety for attracting bigger audiences. Searching for their identity in the transforming social and market environment, the online and traditional media are serving more eagerly to advertisers rather than audiences. Because of the quicker reaction to breaking news events, online-only media slowly but steadily take over the niches in the breaking news areas, competing successfully with the traditional print media.

In addition to traditional media and online-only news sites, some citizen-generated content has entered the World Wide Web. The Internet is used for the so-called "citizens' journalism". Weblogs on different social and political issues have multiplied. Using other social media platforms, as well as networking and microblogging services such as Facebook, Google Plus, Instagram, Twitter, and hashtags are becoming more and more popular.

Irrespective of the fast development of new media and of taking the public debate online, television is still the most trusted medium in the Bulgarian society: $64 \%$ against $45 \%$ for the radio, $42 \%$ each for the Internet and 35\% for the press [European 2014].

\section{MEDIATIZATION OF POLITICS AND POLITICIZATION OF MEDIA²}

During the period of twenty-five years, the Bulgarian citizens voted 23 times (on average, once yearly). Starting with the vote for the Grand National Assembly (in 1990), they went through five presidential elections (in 1992, 1996, 2001, 2006, and 2011), seven parliamentary elections (in 1990, 1991, 1994, 1997, 2001, 2005,

2 The topic has been analyzed by the author in the following publications: Media Projection of the Local Elections after 1989 (Burgas Municipality - Bulgaria), co-authored with Y. Shapovalova, 2011, Available at: http://true-european-voter.eu/node/90; Similarities and Differences in Transformational Democra- 
2009, and 2013), six local elections (in 1991, 1995, 1999, 2003, 2007, and 2011), three European parliamentary elections (in 2007, 2009, and 2014), one referendum and the appointment of fourteen governments.

The dynamics of pre-election campaigns during the period of democratization since 1989, has been developing alongside demonopolization, liberalization and transformation of the media system. The deregulation of the radio and TV broadcasting sector dragged on, thus two mutually bound processes developed - politicization of media and mediatization of politics.

In spite of the fact that a considerable step towards democratization has been made in Bulgaria, the political system faces in its functioning an immense challenge of appearance-keeping, owing to non-clarified identity, both at conceptual and at representative level. The long years of one-party dominance were replaced by an ever-cropping host of new political parties, unions and organizations, which constantly split, regrouped and entered into coalitions, especially on the eve of forthcoming elections. Breaking of the bipolar model with the help of some newly formed structures of the leadership type has failed to bring about sustainability to the political system which is weighed down by heavy economic and social problems. The model of democracy that is on the make in the country delegated the difficult tasks of transition to the political elite and eliminated the broad participation of the people in the process of transformation. Although superficially heterogeneous, the political as well as the media environment (especially in pre-election times) are still not aware of the parameters of pluralism, or of independence too. In terms of this, the media fail to meet the expectations and to carry through their chance of contributing effectively to the process of transformation of the society, because of failing to seek its active participation [Gross 2001].

On the other hand, politicians fail also to carry through the necessary reforms that would meet the European choice of the country and the expectations of the people. Even the unique Bulgarian ethnic model, formed after long years of effort on the part of all ethnic groups and not by the contemporary parties and politicians, has been put to rather abusive ends. The ever deeper yawning gap between rulers and society has proved a grave obstacle for the trust and entrepreneurship of citizens. The absence of distinct program platforms encourages inter-party migration and erodes the foundations of political pluralism, decreasing progressively election activity: from $90.79 \%$ in the first round of elections for the Grand National

cies: EP Campaigns in Bulgaria and Hungary, co-authored with J. Róka, [in:] Political Communication in European Parliamentary Elections, M. Maier, J. Strömbäck, L. Kaid (eds.), Ashgate, Surrey, England 2011, pp. 61-74; Election News Coverage in Bulgaria, co-authored with D. Dimitrova, [in:] The Handbook of Election News Coverage around the World, J. Strömbäck, L. Kaid (eds.), Routledge, New York, USA 2008, pp. 341-356; Fifteen Years of Televised Political Advertising in Bulgaria, [in:] The Sage Handbook of Political Advertising, L. Kaid \& C. Holtz-Bacha (eds.), Sage Publications, Thousand Oaks (Ca), USA 2006, pp. 359-375; The Impact of Television on the Democratization Processes, [in:] Handbook of Political Marketing, B. Newman (ed.), Sage Publications, Thousand Oaks, London, New Delhi 1999, pp. 485-505. 
Assembly in 1990, to $28.6 \%$ in the first elections for the European Parliament in Bulgaria in 2007, and further down to $20.22 \%$ for the First National Referendum in 2013. ${ }^{3}$ Slowly but certainly, Bulgarian electors refuse to yield to the instruments of political, sociological and media propaganda, reject to join the process of social substitution and have acquired a position of active passiveness. As a result, the efforts for state regulation fail to effectively overcome self-regulation traced back to the dawn of democratic changes achieved at the National Round Table, back in 1990. An example is the Code of Conduct for Elections which postulates as unwarranted the offering, demanding, giving out, or promising of any monetary amounts, or of any other advantage against the elector's signature in support of, or for nomination of a candidate, or for voting in favor of any political party, movement or an independent candidate [Documents 1990]. The observance of this self-regulatory norm has proved unattainable for participants in the election race in the country and thus years later it had to be legally decreed that the purchase and sale of votes is a criminal offence. However, this mantra repeated as a must after every piece of political advertising has failed to rid the country of the problem.

For nearly a quarter of a century, political, economic and social upheavals significantly impacted the development of the mass media system in Bulgaria towards quick and flexible reactions to the social processes. At the beginning of the transition period, the spirit of the changes was felt at the open meetings and rallies in Sofia for a full year. In the areas outside the capital, the changes were felt mainly because of television coverage. That is why the organizers of protest rallies in support of change in the capital made sure they marched past TV headquarters. The significance of television was manifested in several critical situations during the years, including: the TV attack against President Petar Mladenov in 1990 that compelled him to resign; the resignation of the Bulgarian Socialist Party government headed by Andrey Loukanov in 1990; the mass media war launched by the Union of Democratic Forces government of Philip Dimitrov, which led to its toppling in 1992; the exit of the government of Lyuben Berov (under the Movement for Rights and Freedom mandate) in 1994; the withdrawal of the Bulgarian Socialist Party government of Zhan Videnov in 1996; the siege of the House of the National Assembly in the situation of a governmental crisis in 1997, which led to radical power shift; the forced restructuring of the Union of Democratic Forces government of Ivan Kostov in 1999, based on corruption allegations; the attacks that brought about ministerial replacements in the Simeon Saxe-Coburg-Gotha government in 2005 and in the three-party coalition (Coalition for Bulgaria, Movement for Rights and Freedoms and National Movement Simeon II) government of Sergei Stanishev; the constant corrective to the government of Boyko Borisov (Citizens for European Development of Bulgaria) and the wide coverage of the social protests which led to the earlier resignation of this government in 2013; the coverage of the pressure of the continuous social protests

3 Data from the archives of the Central Election Commission. 
against the government of Plamen Oresharski (Coalition for Bulgaria) which also led to its earlier resignation in 2014.

The country still lacks a stable foundation on which to test the maturity and professionalism of the media under the opportunity for informed choice on the part of the voters in the conditions of representative democracy. The varied TV media environment experiences the lack of self-regulation reflexes. The market mechanisms prove stronger than the social responsibility norms and abiding by professional standards. The vague legal framework of media legislation; the formal application of the European Directive on Audiovisual Media Services; the lack of adequate definition and regulation of political advertising; the unregulated product placement of political subjects and of political markers for audiovisual identification; the imprecise financial and program rules for the election campaigns which favor the commercial media outlets; the deviations of sociological surveys and conscious self-regulation inertness on the part of providers of media services; the inadequate reactions of the non-government sector; the deprofessionalization of journalists and the creative deficit in the audiovisual domain are all robust factors which push the media away from the democratic values and involve them into the spiral motion of obscure political and corporative interests. Professional inadequacy and bias of some political scientists, sociologists and media professionals is often displayed during the campaigns. As a result, although a considerable progress has been achieved in audiovisual quality of the political advertising products, the media system still fails in fulfilling its major purpose in pre-election times, namely, to inform society impartially and on equal footing about the participants in the political race and their platforms.

The process of creating legislation, its optimization, consolidation and harmonization with the EU aquis communautaire still suffer lapses in the formulation of clear definitions, decrees and effective documents for the organization and TV coverage of the election campaigns. For example, in the Election of the Grand National Assembly Act (1990), only one article explained the access of candidates to the Bulgarian National Television - the public service broadcaster. In 1994, its regional radio and TV centers were also allowed to take part in political campaigning. In 1997, the commercial TV broadcasters joined in election advertising. Regulation of the election campaigns was described in detail in 24 articles of the Election Code of 2011, as well as in its revision of 2014. Nevertheless, legislation and regulatory practices of the various election campaigns have not been structured with sufficient precision and often the Central Election Commission was delegated the right to specify the order for their conducting. The parliamentary represented political forces are still in a more favorable position with respect to the media access than those which are outside the National or the European Parliament. The growing number of the opinions of the non-voters is neglected on the screen.

Financial sanctions for unregulated violation of the legal norms during elections are strangely low and ineffective, in order to conduct free, fair and democratic elections and to obtain honest media coverage of the process of national vote. Attempts 
at coordinated self-regulation between the parties, sociologists, PR agencies, media, non-government sector, and the academic community have proved fragile and unstable. Apparently, for the effective functioning of the political system, it is necessary to revise the legislative framework and to improve its regulatory application.

Since the turn of the century, all the elections (parliamentary, presidential, local, and for MEPs) have been conducted under the conditions of a competitive media system strategically used for political campaigning. Both campaigns and election returns, however, manifested grave professional problems in the domain of sociology and the media that failed to meet the requirement for unbiased information and predictability of election results. The paradox is that Parliament $(2001,2005$, and 2013) and President (2001) were elected contrary to sociological forecasts. A steady tendency of low voter turnout has been registered in all the elections.

In contemporary Bulgarian society, the media have gained position of a main source of information about politics and a transmitter of its communication techniques. Along with this, developing under the conditions of new technological parameters and business models, they are facing the great challenge of retaining their social purpose in society. This task becomes ever more difficult to accomplish not only owing to the multi-channel character of communication, but also owing to the growing selectivity of a fragmented audience, which turns into an active user, both consumer and producer of information. Thus, the media, and especially the television, involuntarily or on purpose press on society its personalized matrix and in the process of coverage of the world events increasingly sink into a mantra of their own reality, removed from its genuine parameters. A dangerous for democracy interpenetration of the media, capitals and politics comes to the fore, which leads to auto-censure and twists in functionality of the free journalism. Although the media system has drastically changed in a very short period, the trailing in time deregulation, the commercialization and the neglect of professional standards have preconditioned distortions in normal functioning of the market and in the development of two interlinked processes: politicization of the media and mediatization of the politics.

\section{THE FACEBOOK IMAGE OF THE SOCIAL PROTESTS IN BULGARIA ${ }^{4}$}

Within the framework of less than a year, after the spur of the Arab Spring of 2011, the spontaneously organized, thanks to the social networks, mass protests across the world have managed to redefine the communication processes. The traditional

4 The topic has been analyzed by the author in the following publications: The Facebook Image of the 2013/2014 Social protests in Bulgaria, co-authored with M. Tomov, [in:] Democracy and Media in Central and Eastern Europe 25 Years on, B. Dobek-Ostrowska, M. Głowacki (eds.), Peter Lang Edition, Wrocław, Poland 2015, pp. 166-181; Interactivity as a Metaphor of Online News, co-authored with L. Fortunati, H. Harro-Loit, J. O'Sullivan, "Javnost, Journal of the European Institute for Communication and Culture", December 2010, pp. 43-61; Television: The Stepmother?, [in:] Media Freedom and Pluralism: 
media, especially the radio and TV, in spite of their simultaneous nature, were lagging dramatically behind in the high-speed race for consumers' attention. The Protester - starting from the Arab Spring to Athens and from Occupy Wall Street to Moscow - was proclaimed the Person of Year 2011 by the American "Time" magazine.

Although with a small group, Sofia was one of nearly 1,000 cities in more than 80 countries which supported the global OCCUPY initiative. Self-organized via the social networks in June 2012, Bulgarian environmentalists blocked out the traffic in the area of Sofia's Orlov Most (Eagles' Bridge) protesting against the amendments to the Forestry Law.

The occupied Orlov Most became the emblematic agora for leaderless rhisomatic ${ }^{5}$ social marches in the winter of 2013, which brought about an early resignation of the center-right government of Citizens for European Development of Bulgaria political party. The anti-monopoly protests started late in January 2013 in the towns of Sandanski and Blagoevgrad and in less than a month spread to over thirty other Bulgarian towns. Initially, they were incited by the high electricity bills and were aimed against the monopolists in the government-regulated market of electricity, water supply and heating ${ }^{6}$. Subsequently, the protests escalated against the political system functioning during the 23-year-long transition period. Protesters symbolically burned their bills.

Media Policy Challenges in Enlarged Europe, B. Klimkiewicz (ed.), CEU Press, Budapest, Hungary 2010, pp. 125-155; Tracing the Digital Switchover in an Enlarged Europe, "Communication, Politics \& Culture Journal”, School of Media \& Communication. RMIT University, Melbourne, Australia 2010, vol. 43, no. 2, pp. 83-98; Television: The Good, the Bad and the Unexpected Challenges of ICT, [in:] Participation in Broadband Society: Interacting with Broadband Society, L. Fortunati, J. Gebhardt, J. Vincent (eds.), Peter Lang GmbH, Frankfurt am Main, Germany 2010, vol. 1, pp.187-205; Television: the Challenges of the Digital Dividend to Viewers Participation, [in:] The Good, the Bad and the Challenging. The User and the Future of Information and Communication Technologies, B. Sapio, L. Haddon, E. Mante-Meijer, L. Fortunati, T. Turk, E. Loos (eds.), Office for Official Publications of the European Communities, Luxembourg 2009, vol. 1., pp. 477-485; Television, the Fragile Virtual Shelter?, "Media Research. Croatian Journal for Journalism and the Media" - Media and the Public Interest, 2009, vol. 15, no. 2, pp. 81-102; The Challenges of ICT to Media Pluralism, [in:] Press Freedom and Pluralism in Europe. Concepts and Conditions, A. Czepek, M. Hellwig, E. Novak (eds.), Intellect, Bristol, UK 2009, pp. 75-90; Television: The Good, the Bad and the Unexpected Challenges of ICT, [in:] The Good, the Bad and the Unexpected. The User and the Future of Information and Communication Technologies, B. Sapio, L. Fortunati, L. Haddon, K. Kommonen, E. Mante-Meijer, T. Turk (eds.), ABS Center, Koper, Slovenia 2008, vol. 1, pp. 580-594; DTV in Bulgaria, [in:] Digital Television in Europe, W. Van den Broeck, J. Pierson (eds.) VUB Press Brussels 2008, pp. 23-31; Tracing the Digital Switchover in Enlarged Europe, [in:] Digital Television Revisited, A. Urban, B. Sapio, T. Turk (eds.), COST Action 298: 'Participation in the Broadband Society' 2008, pp. 155-164; Television: the Challenges of Pluralism to Media Regulation, "Central European Journal of Communication. Official Journal of Polish Communication Association”, vol. 1, no. 1, 2008, pp. 63-78.

5 The term "rhisomatic" was introduced by the French post-modern philosophers Gilles Deleuze and Félix Guattari to denote the acts of non hierarchical multitude described in their two-volume work Capitalism and Schizophrenia (1972-1980).

6 Electrical power distribution in Bulgaria was managed by a state-owned monopoly until 2005, when the government sold $67 \%$ of it to three foreign power companies - German E.ON, Austrian EVN Group and Czech ČEZ Group. In 2011, E.ON sold its Bulgarian branch to the Czech Energo-Pro, and in the next year, the state sold its stakes in ČEZ. EVN, ČEZ and Energo-Pro virtually operate as private regional monopolies whose activities are overseen by the State Commission for Energy and Water Regu- 
Key motorways and transport routes in the country were blocked; bottles, eggs and stones were thrown against gendarmerie and police units, the buildings of the Ministry of Economy and of the National Assembly in the capital of Sofia.

The media, and especially the TV coverage of the series of multiplying protest cases of self-immolation or self-infliction of bodily injuries, has prompted the Council for Electronic Media to publish a special Declaration addressed to Providers of TV Services. The regulating authority stipulated in it that 'close-ups of traumatic images - scorched clothes, details from the sites, photographs of the faces which allow their clear identification - are being circulated. Objects of enhanced journalistic interest are also the relatives and friends of the victims, without always avoiding the risk of their secondary victimization.' By that Declaration, CEM appealed to the Bulgarian media to show more concern for the life and health of the citizens, while covering the civil protests without underestimation of the right to information and within the framework of their editorial independence [Council 2013].

As a result of this public tension, less than a month from the beginning of the protests, on February 20, 2013, the day after the clashes between the police and the protesters led to bloodshed and a number of civilians were badly injured, the Prime Minister Boyko Borisov announced that his cabinet would resign. A caretaker government was appointed to serve until elections that were originally scheduled to be held in July, but had to be brought forward.

The Parliamentary Election of May 12, 2013 resulted in a hung parliament, with no party winning with a majority of seats. The voter turnout was at its lowest since the major political changes of 1989. As the party winning a plurality (97 out of 240 seats), Citizens for European Development of Bulgaria had the opportunity to form a government, however, it could not get support by the other three parties - the Bulgarian Socialist Party (84), the Movement for Rights and Freedoms (36) and the nationalist political party Attack (23). Thus, the government was appointed with the mandate of the Bulgarian Socialist Party, supported by the Movement for Rights and Freedoms - altogether they have 120 seats. The quorum was secured by the nationalistic political party Attack - the major opponent of the Movement for Rights and Freedoms - a telling political deal.

Only two days after the appointment of the new government (with PM Plamen Oresharski) on May 29, 2013 protests were organized against it, but they burst out on June 14. In a matter of hours and again, as in February, via the social networks, more that 10,000 people spontaneously self-organized themselves to march in a massscale peaceful protest in Sofia against the Parliamentary appointment of 31-year-old Delyan Peevski - a MP from the Movement for Rights and Freedoms (MRF) and an owner of a media conglomerate. He was not transparently nominated by the Bulgarian Socialist Party and Movement for Rights and Freedoms to head the Bulgarian State

lation (SCEWR). The state also sold its power distribution infrastructure to them and lost control over the management of profits. 
Agency for National Security (DANS). The public anger was exacerbated by the fact that in the days leading up to Peevski's election, the Parliament had approved major changes in the legal framework of DANS structures, which gave its head an unprecedented power.

Although Peevski's nomination was quickly revoked, the protests against the lack of transparency and integrity on the half of the rulers have acquired a chronic character. The demonstrations were noted for their use of social networks. Every day, for more than six months, in the early evening hours, thousands took part in the anti-government demonstrations. A mass-scale organizational effect was achieved by using the hashtag \#danswithme ${ }^{7}$ from Facebook and Twitter at the beginning of these protests, which enabled those who did not attend the event, to follow them virtually.

The government did not respond effectively to the calls for new elections and public accountability and the protesters have resorted to other means of expressing their anger, such as the initiative of drinking coffee every morning in front of the Parliament; randomly blockading key roads; organizing creative happenings, etc. The demonstrations have been largely peaceful. Nevertheless, on July 23, because of the intention of the government not to transparently amend the 2013 State budget, demonstrators, summoned again via social networks, blockaded the house of the Bulgarian Parliament with trashcans, park benches, paving stones and street signs. A significant number of MPs and ministers were trapped inside the building for more than eight hours. Despite the mounting pressure and the growing people's discontent, the government largely ignored the protesters and dismissed their claims. On the contrary, a counter-protest in support of the Oresharski cabinet, and against President Plevneliev (who has supported the anti-government protests), although with much lower attendance, was organized. Supporters of the government insisted that it should be given a chance to work.

Although some executive measures for lowering the electricity bills have been taken, yet again they did not seem to be sufficient, clearly outlined and sustainable. The Anti-government Information Agency NOresharski!, distributed online, cited the opinion poll by the Alpha Research Agency, which pointed out that $51 \%$ of respondents support the anti-government protests demanding resignation of the government, $33 \%$ support the counter protests in favor of the government, while $16 \%$ do not support either protest [NOresharski 2013].

National demonstrations in all major cities were also supported by the Bulgarian Diaspora, protesting in front of the Bulgarian embassies and consulates across Europe: Athens, Barcelona, Berlin, Brussels, Dublin, Düsseldorf, Frankfurt, London, Madrid, Munich, Paris, Vienna, as well as in many other major cities all over the world. All these protests were organized mainly via the social networks.

7 Bulgarian State Agency for National Security (in Bulgarian the abbreviation is 'DANS' used as a pun for 'dance'). 
Although all of the 2013 protests have been extensively covered and commented by the mainstream media, the communication was enhanced greatly by the information streaming in the social networks.

Media transformation is catalyzed now by the opportunities presented by the blogosphere and the social networks; by the mobile information and communication technologies, with all this leading to basic changes in the media paradigm - from means for mass information to services for individual media consumption. Thus, in the age of hyper modernity and of multiplication of information sources, the public discourse is mediatized and leads to significant structural transformations in the public sphere. The contemporary technologically determined information and communication environment is not only facilitating users' participation in the process of generation and dissemination of content, but is also creating new opportunities for democratic citizenship. The media and their audiences are subject to broad diversification under the growing importance of the public opinion and the development of consumer culture.

\section{CONCLUSIONS}

The major trends in the development of contemporary communication processes, such as technological convergence; media and communication trans-nationalization; obscuring of demarcation lines between the commercial and public media territories; commodity approaches leading to manipulation of audiences; fragmentation and specialization of the media consumption; genre hybridization, etc. have their great impact on contemporary Bulgarian media developments and sustaining media freedoms. Nearly half a century after the outset of political and economic changes and in spite of the considerable advancement towards democratization in the country, still some grave challenges could be outlined facing the transformation processes of functioning of the media system in Bulgaria:

- created pluralistic media system, despite its diversification, does not have a clear-cut identity, both on conceptual and on professional level;

- creation of the normative basis, its optimization, consolidation and harmonization with the European Community aquis communautaire still suffer of imperfections in the definitions, decrees and regulation instruments for media system functioning. The attempts at coordinated self-regulation and co-regulation between the professional guild, non-government sector and regulators have proved fragile and untenable;

- in spite of its diversification, the media environment lacks strongly self-regulation reflexes. Although heterogeneous, the world media still fails to apply effectively the parameters of pluralism as the main principle of journalistic independence. The market mechanisms have proved stronger than the norms of social responsibility and attachment to professional standards. Irrespective 
of the rapid development of the new media and of taking the public debates online, the television and radio still enjoy greater trust of the Bulgarian society, as compared to the online editions and printed media.

Tracing out the processes in the contemporary media system, several trends, which are important for its future functioning in support of its independence, could be outlined:

Technological: The territory of media contents distribution will continue to expand via various communication platforms into diverse hybrid forms - media, media-like, personal, corporative, etc.

Economic: Convergence of production and distribution of the audiovisual contents, as well as emergence of a new type of communicators will encourage the development of new business models.

Legal: Updating of the main documents and development of new ones will be further intensified in the future in relation to functioning of the media system within the globalizing informational and communication environment.

Social: The technological innovation would require a more substantial defense of the main rights and freedoms of the citizens (access to information, freedom of speech, diversity of sources, pluralism of viewpoints, protection of minors and persons under age, etc.), of the professional and ethical journalistic standards (ensuring informed opinion in the election campaigns, avoiding hate language and violation of privacy, etc.)

Professional: The multi-functional requirements to journalists working in the convergent media environment would increase. Application of the information and communication technologies would entail further development of the media ecosystem, namely diffusion of the blogs with the genres of traditional journalism. The new applications will facilitate the creation of media content by the consumers, which, in turn, would influence editorial organization and practice and would step up democratization of the information exchange.

Regulatory: Public responsibility of the producers and distributors of audiovisual media services should be guaranteed by higher effectiveness and the joint efforts of regulation, self-regulation and joint regulation under the conditions of observance of editorial independence and preservation of the model of public media.

Dynamism of the processes in the media environment is so intensive that it has proved difficult to establish a distinct many-sided coordination of its role in the contemporary period: Is it an essential part of the democratic layout of the country, or an independent trans- and supranational system operating on the principle of the free market enterprise? In other words, would it develop under the condition of increasing stronger deregulation prompted by the technological and economic convergence in favor of the market, or in favor of joint regulation serving effectively the interests of society? Furthermore, the media system is steadily getting rid of its mass character, the reception of information is ever more personalized and commerce is displacing the public character of the messages. Genre diffusion and variety of platforms call 
for new formats of the contents, enabling the viewer himself to create and distribute information. Under such conditions, especially important is the problem of the so dangerous for democracy interpenetration of the media, capitals and politics, which entail self-censorship and bending of functionality of the free journalism.

\section{BIBLIOGRAPHY}

Constitution of the Republic of Bulgaria, 1991. http://www.Parliament.bg/?page=const\&lng=en (access 18.06.2015).

Council for Electronic Media, 2013. Declaration addressed to Providers of TV Services on the Frequent Cases of Protests through Self-immolation and Self-infliction of Bodily Injuries, http://www.cem.bg/ view.php?id=3246 (access 18.06.2015).

Council for Electronic Media, 2014. Public Register, http://www.cem.bg (access 18.06.2015).

Dobek-Ostrowska, B. 2015. 25 Years after Communism: Four Models of Media and Politics in Central and Eastern Europe, [in:] Democracy and Media in Central and Eastern Europe 25 Years on, B. DobekOstrowska, M. Głowacki (eds.), Peter Lang Edition, Wrocław.

Documents adopted by the National Round Table, 1990. Agreement on the pre-election campaign on radio and television, http://www.omda.bg/public/bulg/k_masa/dokumenti_round_table/agreement_election_campaign.htm (access 18.06.2015).

European Parliament, Report 2014, 1990. Standard Eurobarometer 80: Media Use in the European Union, http://ec.europa.eu/public opinion/archives/eb/eb80/eb80 media en.pdf (access 18.06.2015).

Gross, P. 2001. Entangled Evolutions: Media \& Democratization in Eastern Europe, Johns Hopkins University Press, Baltimore.

Jakubowicz, K. 2008. Finding the Right Place on the Map: Prospects for Public Service Broadcasting in Post-Communist Countries, [in:] Finding the Right Place on the Map. Central and Eastern European Media Change in a Global Perspective. K. Jakubowicz, M. Sükósd (eds.) Intellect, Bristol.

National Statistical Institute, 2009. Radio programs in kind, http://www.nsi.bg/ORPDOCS/Culture_5.2.xls (access 18.06.2015).

National Statistical Institute, 2009. Television programs in kind, http://www.nsi.bg/ORPDOCS/ Culture_6.2.xls (access 18.06.2015).

National Statistical Institute, 2014. Publishing Activity: Books, Newspapers and Magazines, http://www. nsi.bg/en/content/4551/publishing-activity-books-newspapers-and-magazines (access 18.06.2015).

NCPOR, 2012. Socio-political Preferences, http://www.parliament.bg/pub/NCIOM/Bul-02-2012_press. pdf (access 18.06.2015).

NOresharski!, 2013. 51\% of Bulgarians support anti-government protest, http://noresharski.com/?lang=en (access 18.06.2015).

Raycheva, L. 1999. The Impact of Television on the Democratization Processes, [in:] Handbook of Political Marketing, B. Newman (ed.), Sage Publications, Thousand Oaks-London-New Delhi.

Raycheva, L. 2000. The Dynamics of the Electronic Mass Media System in Bulgaria (1989-1999), "The Global Network", no. 13.

Raycheva, L. 2003. Mass Media in Bulgaria, [in:] A Source Book. Dortmund 2003: ENTIRE - Working Papers in International Journalism.

Raycheva, L. 2003. The Challenges of Internet Media to Traditional Media System in Bulgaria, [in:] Towards New Media Paradigms: Content, Producers, Organizations and Audiences, R. Salaverria, S. Sádaba (eds.), Eunate, Pamplona.

Raycheva, L. 2006. Fifteen Years of Televised Political Advertising in Bulgaria, [in:] The Sage Handbook of Political Advertising, L. Kaid \& C. Holtz-Bacha (eds.), Sage Publications, Thousand Oaks. 
Raycheva, L. 2006. Television in Bulgaria on the Net, [in:] The Impact of Internet on the Mass Media in Europe, N. Leandros (ed.), Abramis, Bury St. Edmunds, Suffolk.

Raycheva, L. 2008. DTV in Bulgaria, [in:] Digital Television in Europe, W. Van den Broeck, J. Pierson (eds.) VUB Press, Brussels.

Raycheva, L. 2008. Television: the Challenges of Pluralism to Media Regulation, "Central European Journal of Communication" the official Journal of the Polish Communication Association, vol. 1, no 1.

Raycheva, L. 2008. Television: The Good, the Bad and the Unexpected Challenges of ICT, [in:] The Good, the Bad and the Unexpected. The User and the Future of Information and Communication Technologies, B. Sapio, L. Fortunati, L. Haddon, K. Kommonen, E. Mante-Meijer \& T. Turk (eds.), ABS Center, Koper.

Raycheva, L. 2008. The Patchwork of Bulgarian Media, "Global Media Journal" - Polish Edition, no. 1(4), http://www.globalmediajournal.collegium.edu.pl/artykuly/wiosna\%202008/raycheva-bulgaria.pdf.

Raycheva, L. 2008. Tracing the Digital Switchover in Enlarged Europe, [in:] Digital Television Revisited, A. Urban, B. Sapio, T. Turk (eds.), COST Action 298: 'Participation in the Broadband Society'.

Raycheva, L. 2009. Mass Media Developments in Bulgaria, [in:] Press Freedom and Pluralism in Europe. Concepts and Conditions, A. Czepek, M. Hellwig, E. Novak (eds.), Intellect, Bristol.

Raycheva, L. 2009. Television, the Fragile Virtual Shelter?, "Media Research. Croatian Journal for Journalism and the Media", vol. 15, no 2.

Raycheva, L. 2009. Television: the Challenges of the Digital Dividend to Viewers Participation, [in:] The Good, the Bad and the Challenging. The User and the Future of Information and Communication Technologies, B. Sapio, L. Haddon, E. Mante-Meijer, L. Fortunati, T. Turk, E. Loos (eds.) Office for Official Publications of the European Communities, Luxembourg.

Raycheva, L. 2009. The Challenges of ICT to Media Pluralism, [in:] Press Freedom and Pluralism in Europe. Concepts and Conditions, A. Czepek, M. Hellwig \& E. Novak (eds.), Intellect, Bristol.

Raycheva, L. 2010. Television: The Good, the Bad and the Unexpected Challenges of ICT, [in:] Participation in Broadband Society: Interacting with Broadband Society, L. Fortunati, J. Gebhardt, J. Vincent (eds.), Peter Lang GmbH, Frankfurt am Main.

Raycheva, L. 2010. Television: The Stepmother?, [in:] Media Freedom and Pluralism: Media Policy Challenges in Enlarged Europe, B. Klimkiewicz (ed.), CEU Press, Budapest.

Raycheva, L. 2010. Tracing the Digital Switchover in an Enlarged Europe, "Communication, Politics \& Culture", vol. 43, no. 2.

Raycheva, L. 2012. The Challenges of Digitalization to Bulgarian Public Service Media, [in:] Public Value Report, K. Mitschka (ed.), ORF, Austria.

Raycheva, L. Dimitrova, D. 2008. Election News Coverage in Bulgaria, [in:] The Handbook of Election News Coverage around the World, J. Strömbäck, L. Kaid (eds.), Routledge, New York.

Raycheva, L. Petev, T. 2000. Mass Media System in Bulgaria (1989-1999), “The Global Network”, no. 13 Raycheva, L. Petev, T. 2003. Mass Media's Changing Landscape in Bulgaria, [in:] Business as Usual. Continuity and Change in Central and Eastern Europe, D. Paletz and K. Jakubowicz (eds.), Hampton Press, Inc. Cresskill, New Jersey.

Raycheva, L. Róka, J. 2011. Similarities and Differences in Transformational Democracies: EP Campaigns in Bulgaria and Hungary, [in:] Political Communication in European Parliamentary Elections, M. Maier, J. Strömbäck, L. Kaid (eds.), Ashgate, Surrey.

Raycheva, L. Tomov, M. 2015. The Facebook Image of the 2013/2014 Social Protests in Bulgaria, [in:] Democracy and Media in Central and Eastern Europe 25 Years on, B. Dobek-Ostrowska, M. Głowacki (eds.), Peter Lang Edition, Wrocław.

Raycheva, L., Shapovalova, Y. 2011. Media Projection of the Local Elections after 1989 (Burgas Municipality - Bulgaria), available at: http://true-european-voter.eu/node/90.

Raycheva, L., Fortunati, L. Harro-Loit, H., O’Sullivan, J. 2010. Interactivity as a Metaphor of Online News, "Javnost, Journal of the European Institute for Communication and Culture", December. 
Raycheva, L., Stoyanova, P. 2012. The Bulgarian-Language Media Diaspora, [in:] Migration, Diaspora, and Information Technology in Global Societies, L. Fortunati, R. Pertierra, J. Vincent (eds.), Routledge, New York.

Reporters Without Borders, 2015. 2015 World Press Freedom Index, https://index.rsf.org/\#!/ (access 18.06.2015).

Union of Bulgarian Journalists, 2004. Code of Ethics of Bulgarian Media, http://www.sbj-bg.eu/index. php?t=58 (access 18.06.2015).

\section{BIOGRPAHY}

Lilia Raycheva, PhD, Professor at the Radio and Television Department of the Faculty of Journalism and Mass Communication of the St. Kliment Ohridski University of Sofia. She has served as Vice-Dean for Scientific Research and International Affairs (1998-2001) and Head of Radio and Television Department (1999-2001). For seven years she has also served as a member of the Council for Electronic Media - the regulatory authority for radio and television broadcasting in Bulgaria (2001-2008) and as a member of the Standing Committee on Transfrontier Television at the Council of Europe (2005-2008). She has been extensively published. She is the author of 4 books, numerous scientific publications and the editor of 14 books. Her main scholarly interests include communication and media studies, audio-vision, and political communication. Her professional authorship portfolio includes a large number of TV programs. E-mail: 1raycheva@yahoo.com 